\title{
Kinerja keuangan perusahaan asuransi jiwa di Indonesia berdasarkan tingkat profitabilitas
}

\author{
Laksmita Febriyanti*; Muhammad Ananda Raf'i; Rahmat Dimas Darmawan; \\ Robby Kurnia; Dewi Hanggraeni
}

\author{
Fakultas Ekonomi dan Bisnis, Universitas Indonesia \\ *E-mail korespodensi: laksmitaf@gmail.com
}

\begin{abstract}
This study investigates the main determinants of the profitability of life insurance companies in Indonesia. It examines the relationship between the profitability of insurance companies, namely investment income, underwriting profit, and overall net profit. The annual financial reports of ten life insurance companies in Indonesia covering ten years (2010-2019) were sampled and analyzed through panel regression. The findings indicate that gross written premium has a negative effect on overall net profit, yet a positive impact on the underwriting profit of insurance companies. Furthermore, there is a positive relationship between claim payments and the overall net profit of life insurance companies. Further research revealed a positive relationship between total assets and indicators of profitability. The policy implications of this study for insurance industry stakeholders are far-reaching. This study fulfills an urgent need to investigate issues critical to life insurance companies' sustainability, growth, and profitability in developing countries.
\end{abstract}

Keywords: Life insurance companies, Company's financial performance, Indonesia's insurance companies

\begin{abstract}
Abstrak
Studi ini bertujuan untuk menyelidiki faktor penentu utama profitabilitas perusahaan asuransi jiwa di Indonesia dan menguji hubungan antara profitabilitas perusahaan asuransi, yaitu pendapatan investasi, keuntungan underwriting, dan laba bersih keseluruhan. Laporan keuangan tahunan sepuluh perusahaan asuransi jiwa di Indonesia yang mencakup periode 10 tahun (2010-2019) diambil sampelnya dan dianalisis melalui regresi panel. Temuan menunjukkan bahwa premi bruto memiliki pengaruh negatif terhadap laba bersih keseluruhan, namun memiliki pengaruh positif terhadap keuntungan underwriting perusahaan asuransi. Selanjutnya, terdapat hubungan positif dari tingkat pembayaran klaim dengan laba bersih keseluruhan perusahaan asuransi jiwa. Hasil penelitian lebih lanjut mengungkapkan hubungan positif antara total aset terhadap seluruh indikator tingkat profitabilitas. Implikasi kebijakan dari penelitian ini bagi para pemangku kepentingan industri asuransi sangat luas jangkauannya. Studi ini memenuhi kebutuhan mendesak untuk menyelidiki hal-hal penting bagi keberlanjutan, pertumbuhan, dan profitabilitas perusahaan asuransi jiwa di negara berkembang.
\end{abstract}

Kata kunci: perusahaan asuransi jiwa, kinerja keuangan perusahaan, perusahaan asuransi Indonesia

\section{PENDAHULUAN}

Perusahaan asuransi memberikan layanan keuangan yang unik untuk pertumbuhan dan perkembangan setiap perekonomian. Layanan keuangan unik tersebut 
berkisar dari penjaminan risiko yang melekat pada entitas ekonomi sampai mobilisasi dana dalam jumlah besar melalui premi untuk investasi jangka panjang. Peran penyerapan risiko dari perusahaan asuransi mempromosikan stabilitas keuangan di pasar keuangan dan memberikan "rasa damai" bagi entitas ekonomi. Dunia bisnis tanpa asuransi tidak berkelanjutan karena bisnis berisiko mungkin tidak memiliki kapasitas untuk menguasai semua jenis risiko dalam ekonomi global yang selalu berubah dan tidak pasti ini (Ahmed N., Ahmed Z., \& Ahmed I., 2010). Kemampuan perusahaan asuransi untuk terus menanggung risiko dalam perekonomian bergantung pada kapasitas mereka untuk menciptakan keuntungan atau nilai bagi pemegang saham mereka.

Industri asuransi yang telah berkembang baik merupakan keuntungan bagi pembangunan ekonomi karena dapat menyediakan dana jangka panjang untuk pembangunan infrastruktur perekonomian (Charumathi, 2012). Profitabilitas perusahaan asuransi dipengaruhi oleh faktor internal dan eksternal. Faktor internal berfokus pada karakteristik khusus perusahaan asuransi, sedangkan faktor eksternal berkaitan dengan fitur industri dan variabel makroekonomi.

Profitabilitas perusahaan asuransi juga dapat dinilai pada tingkat ekonomi mikro, meso, dan makro. Tingkat mikro mengacu pada bagaimana faktor-faktor spesifik perusahaan seperti ukuran, modal, efisiensi, usia, dan struktur kepemilikan mempengaruhi profitabilitas. Tingkat meso dan makro masing-masing mengacu pada pengaruh lembaga pendukung dan faktor makroekonomi. Tiga tingkat faktor penentu profitabilitas perusahaan asuransi ditunjukkan pada Gambar 1. Di tingkat mikro, keuntungan adalah prasyarat penting untuk keberlanjutan, pertumbuhan, dan daya saing perusahaan asuransi dan sumber dana paling terjangkau (Buyinza, Francois, \& Landesmann, 2010). Tanpa keuntungan, tidak ada perusahaan asuransi yang dapat menarik modal dari luar untuk memenuhi tujuan yang telah ditetapkan dalam lingkungan global yang selalu berubah dan kompetitif ini.

Keuntungan tidak hanya meningkatkan kondisi solvabilitas perusahaan asuransi tetapi juga memainkan peran penting dalam meyakinkan pemegang polis dan pemegang saham untuk menyediakan dana ke perusahaan asuransi. Dengan demikian, salah satu tujuan pengelolaan perusahaan asuransi adalah untuk memperoleh laba sebagai persyaratan yang mendasar dalam menjalankan usaha perasuransian.

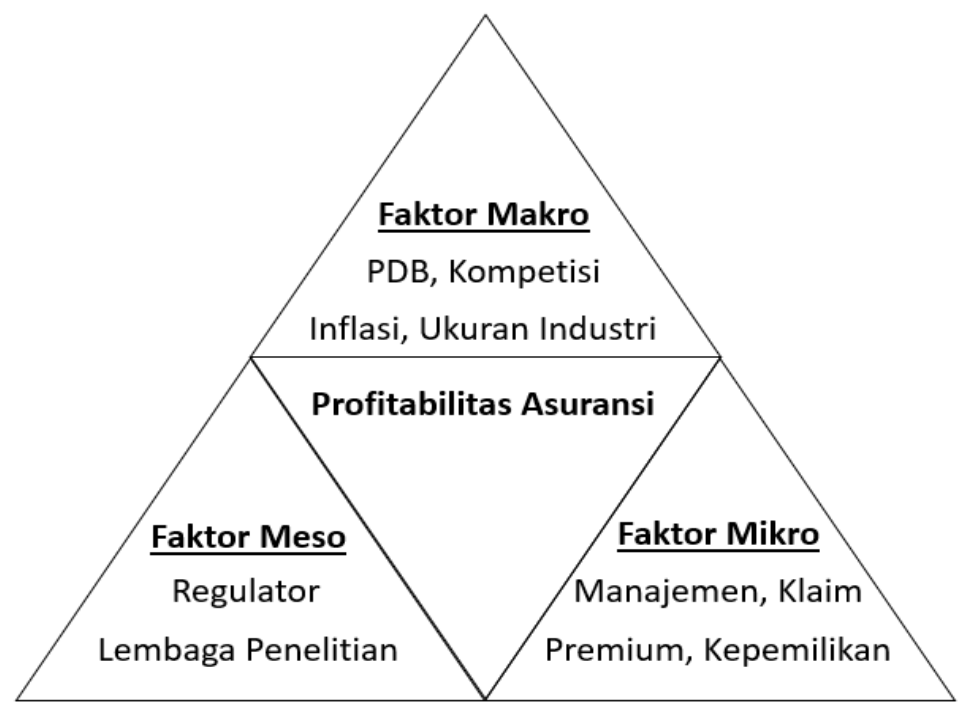

Sumber: Telah diolah kembali dari Akotey, Sackey, Amoah, \& Manso (2013)

Gambar 1. Tiga tingkat faktor penentu profitabilitas di industri asuransi 
Industri asuransi Indonesia telah mengalami perubahan signifikan seperti banyak masuknya perusahaan asuransi asing ke pasar. Perubahan ini telah menghasilkan persaingan yang lebih ketat di industri asuransi. Dengan demikian, merupakan kepentingan setiap perusahaan asuransi untuk mengidentifikasi faktor-faktor penting yang menentukan keberhasilan bisnis. Dengan demikian, penelitian ini berusaha untuk menentukan arah dan kekuatan dari berbagai faktor yang dapat mempengaruhi kinerja keuangan perusahaan asuransi.

Mengidentifikasi indikator kesuksesan utama perusahaan asuransi memfasilitasi desain kebijakan yang dapat meningkatkan profitabilitas industri asuransi. Karenanya, penentu profitabilitas perusahaan asuransi telah menarik minat investor, peneliti ilmiah, analis pasar keuangan, dan regulator asuransi.

Kebanyakan literatur empiris tentang faktor penentu profitabilitas berfokus pada industri perbankan. Sangat sedikit yang diketahui tentang industri asuransi sejauh topik yang dibahas diperhatikan terutama dari perspektif pasar yang sedang berkembang seperti Indonesia. Makalah ini berusaha untuk membuka "gerbang" untuk penelitian ilmiah dan debat akademis yang lebih banyak tentang kinerja keuangan perusahaan asuransi di Indonesia.

Kinerja merepresentasikan potensi dan kapasitas perusahaan untuk mencapai suatu target atau tujuan yang melibatkan konsep pengukuran. Kinerja yang baik merupakan indikator keberhasilan perusahaan yang dapat dievaluasi dalam kerangka persaingan. Kinerja keuangan perusahaan manapun, terutama pengukuran kinerja industri asuransi telah menjadi sangat penting karena perusahaan asuransi memiliki implikasi langsung pada sebagian besar masyarakat sebagai pemegang polis serta calon investor. Kinerja keuangan harus sehat agar perusahaan dapat bertahan dalam industri dan berkontribusi pada pertumbuhan industri. Hal ini lebih relevan untuk industri asuransi jiwa, karena sektor ini menghadapi kerugian pada fase awal sambil menargetkan pertumbuhan jangka panjang (Suvvari, S., \& Goyari, 2019). Terlepas dari berbagai definisi, interpretasi dan pengukuran kinerja keuangan, tidak ada konsensus akhir tentang cara terbaik untuk mengukur kinerja dan untuk mengidentifikasi faktor-faktor yang mempengaruhi kinerja keuangan (Liargovas \& Skandalis, 2010; Omondi \& Muturi, 2013; Sharma, Jadi, \& Ward, 2018).

Untuk sektor asuransi, beberapa studi mengukur determinan kinerja dan risiko asuransi bagi perusahaan asuransi jiwa atau non-jiwa di satu negara atau di berbagai negara. Misalnya, Chang (2006) menganalisis kinerja keuangan 20 perusahaan asuransi Taiwan dengan 19 rasio keuangan dengan menggunakan GRA periode 2000-2002 dan menyimpulkan bahwa profitabilitas dan analisis operasional memiliki pengaruh yang tinggi terhadap kinerja (Chang, 2006; Suvvari et al., 2019). Chen dan Wong (2004) mengungkapkan bahwa ukuran, investasi, dan likuiditas adalah penentu signifikan profitabilitas perusahaan asuransi (Chen \& Wong, 2004; Lee \& Lin, 2016). Dalam studi serupa tentang industri asuransi Pakistan, Ahmed N., Ahmed Z., \& Usman (2011), mengklaim bahwa ukuran dan modal secara signifikan dan positif terkait dengan profitabilitas perusahaan asuransi, sementara leverage memiliki hubungan terbalik yang kuat dengan profitabilitas dan karenanya sangat menurunkan profitabilitas perusahaan asuransi (Ahmed et al., 2011; Lee \& Lin, 2016). Charumathi (2012) menganalisis faktorfaktor yang menentukan profitabilitas 23 perusahaan asuransi jiwa yang beroperasi di India selama periode 2008-2011 dan menyimpulkan bahwa profitabilitas dipengaruhi secara positif oleh ukuran dan likuiditas sedangkan pertumbuhan premi ekuitas modal dan leverage berpengaruh negatif (Charumathi, 2012; Suvvari et al., 2019). Bawa dan Chattha (2013) mempelajari kinerja keuangan dari 18 perusahaan terpilih, termasuk satu 
perusahaan sektor publik untuk periode 2007-2012 dengan menggunakan model regresi berganda (Bawa \& Chattha, 2013; Suvvari et al., 2019). Studi ini menguji pengaruh profitabilitas dan menyimpulkan bahwa profitabilitas perusahaan asuransi jiwa dipengaruhi oleh likuiditas dan ukuran perusahaan, sedangkan modal berhubungan negatif. Burca dan Batrinca (2014) juga melaporkan bahwa ukuran perusahaan merupakan penentu penting kinerja profitabilitas perusahaan asuransi (Burca \& Batrinca, 2014; Kusi, Alhassan, Ofori-Sasu, \& Sai, 2019).

Dalam tinjauan tentang resource-based theory, Zainudin, Mahdzan, dan Leong (2018) mendukung bahwa sumber daya internal suatu perusahaan berperan penting dalam menentukan kekuatan suatu perusahaan (Zainudin et al., 2018; Hemrit, 2019). Dengan demikian, mereka menyimpulkan bahwa ukuran perusahaan adalah sumber daya internal terkuat yang mempengaruhi kinerja keuangan perusahaan asuransi jiwa Asia. Ukuran perusahaan dihitung sebagai logaritma natural dari total aset perusahaan asuransi.

Kumari (2013) meneliti kinerja keuangan perusahaan asuransi publik dan swasta dengan berbagai parameter yang meliputi penetrasi dan kepadatan asuransi, pertumbuhan premi dan ukuran pasar dan menyimpulkan bahwa, setelah liberalisasi industri, kinerja bisnis meningkat (Kumari et al., 2013; Suvvari et al., 2019). Dengan demikian, seperti yang disoroti oleh Mohy Ul Din, Abu-Bakar, dan Regupathi (2017), penetrasi asuransi yang tinggi memberikan peluang untuk menghemat uang, yaitu kemungkinan untuk investasi keuangan dan peningkatan modal untuk meningkatkan cakupan pasar asuransi (Mohy ul Din et al., 2017; Hemrit, 2019). Oleh karena itu, ini berarti bahwa laju penetrasi asuransi yang lebih cepat, serta pemasaran polis asuransi yang efektif kemungkinan besar akan membawa keberhasilan program mobilisasi tabungan, yang akan sangat membantu dalam mencapai kinerja keuangan yang kuat. Perusahaan dengan penetrasi yang lebih tinggi dapat merencanakan secara memadai dan menjalankan strategi kompetitifnya dengan tepat untuk meningkatkan produk dan layanannya, sehingga semakin menguntungkan pembeli (Hemrit \& Benlagha, 2019; Hemrit, 2019). Oleh karena itu, penetrasi asuransi dapat memperbesar diversifikasi dalam manfaat afiliasi individu, dan dengan demikian, meningkatkan kinerja keuangan (Hemrit, 2019). Karena perusahaan asuransi menjual kontrak asuransi, akun premium menjadi pendapatan operasional utama. Oleh karena itu, pertumbuhan premi, premi dibagi dengan premi-1, merupakan faktor kunci yang mempengaruhi kinerja perusahaan asuransi (Barniv \& Hershbarger, 1990; Gron \& Lucas, 1995; Yu, 2015).

Reasuransi dapat meningkatkan surplus perusahaan asuransi yang menyerahkan atau penanggung (Chen, Hamwi, \& Hudson, 2001; Shiu, 2019), manajer dari perusahaan asuransi yang kurang menguntungkan akan cenderung menggunakan lebih banyak reasuransi. Selain itu, perusahaan asuransi ini biasanya memiliki kendala utang yang lebih ketat. Reasuransi secara efektif berfungsi sebagai pengganti sampai tingkat tertentu untuk modal ekuitas (Adiel, 1996; Shiu, 2019), sehingga mereka akan mempertimbangkan kemungkinan menggunakan reasuransi untuk memperluas kapasitas hutang mereka. Lindung nilai reasuransi sangat penting dalam menentukan kinerja keuangan perusahaan asuransi (Shiu, 2019).

\section{METODE}

\section{Sumber data}

Dalam penelitian ini, data diperoleh dari sepuluh perusahaan asuransi jiwa dari 54 perusahaan asuransi jiwa yang berasal dari database direktori asuransi Otoritas Jasa Keuangan (OJK) Republik Indonesia. Sepuluh perusahaan dipilih berdasarkan 
ketersediaan data dan tahun beroperasi perusahaan asuransi tersebut. Laporan keuangan tahunan dari sepuluh perusahaan asuransi jiwa tersebut dianalisis untuk temuan penelitian ini. Laporan keuangan tahunan perusahaan yang dianalisis mencakup periode tahun 2010 - 2019. Informasi mengenai struktur pasar industri asuransi dikumpulkan dari database laporan tahunan OJK. Data mengenai kondisi makroekonomi Indonesia diperoleh dari database Bank Indonesia dan Badan Pusat Statistik Republik Indonesia.

\section{Analisis data}

Pendekatan analisis data panel diadopsi untuk evaluasi faktor penentu profitabilitas perusahaan asuransi. Data panel adalah data longitudinal atau crosssectional dimana entitas ekonomi diamati sepanjang waktu (Ahiawodzi \& Sackey, 2010; Akotey et al., 2013). Penelitian ini mengadopsi gaya ekonometrik Ahiawodzi dan Sackey (2010), Ahmed et al. (2011), Buyinza et al. (2010), dan Kozak (2011) dalam Akotey et al. (2013) untuk pemodelan kerangka ekonometrik penelitian ini. Model regresi untuk data panel berupa:

$$
Y_{i t}=F\left\{X_{i t}, Z_{t}\right\}+\mu_{i t}
$$

dimana $\boldsymbol{Y}_{i t}$ menandakan profitabilitas perusahaan $\boldsymbol{i}$ pada tahun $\boldsymbol{t}, \boldsymbol{X}_{\boldsymbol{i}}$ merupakan vektor dari variabel karakteristik perusahaan i pada tahun $\boldsymbol{t}$ dan $\boldsymbol{Z}_{\boldsymbol{t}}$ merupakan vektor variabel yang mewakili industri asuransi dan faktor makroekonomi pada tahun t. $\mu_{i t}$ adalah istilah error.

Persamaan (1) diperluas dalam model berikut:

$$
Y_{\mathrm{it}}=\beta_{0}+\sum_{m=1}^{m} \beta_{\mathrm{m}} L_{\mathrm{it}}+\sum_{\gamma=1}^{\gamma} \alpha_{\gamma} L \mathrm{I}_{\mathrm{t}}+\sum_{c=1}^{c} \phi_{\mathrm{c}} M F_{\mathrm{t}}+\mu_{\mathrm{it}}
$$

$\boldsymbol{Y}_{i t}$ adalah variabel dependen dan mengukur rasio profitabilitas aktivitas teknis dan aktivitas investasi untuk perusahaan asuransi $\boldsymbol{i}$ pada waktu $\boldsymbol{t}$. Himpunan pertama variabel penjelas $\boldsymbol{L}_{i t}$ adalah akar $\boldsymbol{m}$-th karakteristik khusus asuransi jiwa $\boldsymbol{i}$ pada waktu $\boldsymbol{t}$, sedangkan set kedua variabel penjelas $\boldsymbol{L I}_{\boldsymbol{t}}$ adalah karakteristik industri dari bisnis jiwa pada waktu $\boldsymbol{t}$. $\boldsymbol{M F}_{\boldsymbol{t}}$ adalah variabel independen dan ukuran pengaruh faktor makroekonomi seperti tingkat pertumbuhan produk domestik bruto, inflasi dan suku bunga terhadap profitabilitas perusahaan asuransi.

\section{Spesifikasi model empiris}

Untuk robustness dari hasil yang ditemukan, model empiris dalam penelitian ini digunakan untuk menyelidiki faktor penentu profitabilitas perusahaan asuransi jiwa diestimasi untuk tiga ukuran profitabilitas yang terdapat dalam persamaan (3) - (5). Variabel dependen pertama terdapat dalam persamaan (3), laba bersih keseluruhan (SAP) mengukur keseluruhan profitabilitas perusahaan asuransi dalam kaitannya dengan premi bruto yang ditulis oleh suatu perusahaan. Variabel dependen berikutnya adalah pendapatan investasi (INP) yang mengevaluasi efektivitas portofolio investasi perusahaan asuransi. Kemudian, keuntungan underwriting (UWP) adalah keuntungan dari operasi teknis perusahaan asuransi. Ketiga ukuran ini dapat mengukur efisiensi kegiatan inti perusahaan asuransi (Akotey et al., 2013; Kozak, 2011):

$$
\begin{aligned}
S A P_{i t}= & \beta_{0}+\beta_{1} G W P_{i t}+\beta_{2} M G E_{i t}+\beta_{3} C L M_{i t}+\beta_{4} R E I_{i t}+\beta_{5} L E V_{i t}+\beta_{6} S I Z_{i t}+\beta_{7} I N R_{t}+ \\
& \beta_{8} G D P_{t}+\mu_{i t} \text { (3) }
\end{aligned}
$$




$$
\begin{aligned}
I N P_{i t} & =\beta_{0}+\beta_{1} G W P_{i t}+\beta_{2} M G E_{i t}+\beta_{3} C L M_{i t t}+\beta_{4} L E V_{i t}+\beta_{5} S I Z_{i t}+\beta_{6} I N R_{t}+\beta_{7} G D P_{t} \\
& +\mu_{i t}(4)
\end{aligned}
$$

Data panel dapat dianalisis dengan dua cara, yaitu fixed effect dan random effect models. Fixed effect models menyelidiki hubungan antara hasil dan variabel penjelas dalam suatu entitas, serta mengasumsikan bahwa semua variabel invarian di waktu lainnya pada seluruh entitas yang dapat mempengaruhi variabel penjelas menjadi konstan (Ahiawodzi \& Sackey, 2010; Akotey et al., 2013), namun, random effects mempertimbangkan waktu invarian sebagai terkait secara acak. Tes Hausman pada tingkat kepercayaan 5 persen biasanya digunakan untuk memilih fixed atau random effect untuk analisis regresi panel. Random effect digunakan jika $p$-value (prob. $>\mathrm{X}^{2}$ ) lebih besar dari 0,05, sebaliknya fixed effect menjadi model ideal untuk analisis empiris (Akotey et al., 2013; Torres-Reyna, 2007). Berdasarkan hasil uji Hausman, penelitian ini menggunakan random effect untuk memperkirakan parameter persamaan (3) dan (5) dan fixed effect untuk persamaan (4). Aplikasi IHS EViews versi 11 digunakan untuk mengelola dan menganalisis data dalam penelitian ini. Data pada bagian Hasil dan Pembahasan disajikan dalam satuan milyaran rupiah $(000,000,000)$.

\section{HASIL DAN PEMBAHASAN}

\section{Statistik deskriptif}

Kesimpulan statistik dari variabel-variabel yang digunakan dipaparkan pada Tabel 2. Rata-rata dari tiga pengukuran tingkat profitabilitas penanggung — tingkat laba bersih keseluruhan (SAP), pendapatan investasi (INP) dan keuntungan underwriting

\begin{tabular}{|c|c|c|}
\hline Singkatan & Variabel & Definisi \\
\hline SAP & $\begin{array}{l}\text { Laba Bersih } \\
\text { Keseluruhan }\end{array}$ & $\begin{array}{l}\text { Laba sebelum pajak perusahaan i dibagi dengan total aset } \\
\text { pada waktu t }\end{array}$ \\
\hline INP & Pendapatan Investasi & Pendapatan investasi perusahaan i pada waktu t \\
\hline UWP & $\begin{array}{l}\text { Keuntungan } \\
\text { Underwriting }\end{array}$ & Keuntungan underwriting perusahaan i pada waktu t \\
\hline GWP & Premi Bruto & $\begin{array}{l}\text { Logaritma natural dari premi bruto oleh penanggung i pada } \\
\text { waktu t }\end{array}$ \\
\hline CLM & Klaim & Logaritma natural dari total klaim perusahaan i pada waktu $\mathrm{t}$ \\
\hline REI & Reasuransi & $\begin{array}{l}\text { Total premi bruto yang diberikan perusahaan i pada waktu t } \\
\text { kepada perusahaan reasuransi }\end{array}$ \\
\hline LEV & Total Utang & Total utang perusahaan i pada waktu $\mathrm{t}$ \\
\hline SIZ & Ukuran Perusahaan & Total aset perusahaan i pada waktu $\mathrm{t}$ \\
\hline INR & Tingkat Bunga & BI7DRR setiap bulan Desember \\
\hline GDP & $\begin{array}{l}\text { Produk Domestik } \\
\text { Bruto }\end{array}$ & Pertumbuhan PDB pada waktu $t$ \\
\hline
\end{tabular}
(UWP) — yaitu Rp 869,9 juta, Rp 968,6 miliar, dan Rp 4,878 triliun.

Tabel 1. Definisi variabel dependen dan independen dari model empiris

Sumber: Telah diolah kembali dari Akotey et al. (2013)

Rata-rata beban manajemen (MGE) melebihi rata-rata laba bersih keseluruhan (SAP) lebih dari sepuluh kali. Meskipun begitu, pendapatan investasi (INP) dan 
keuntungan underwriting (UWP) menunjukkan rata-rata yang tinggi dan bisa menutupi beban manajemen.

Tabel 2. Statistik deskriptif perusahaan asuransi jiwa di Indonesia

\begin{tabular}{llllll}
\hline Variable & Obs & Mean & SD & Min & Max \\
\hline SAP & 100 & 0,869903 & 1,584771 & 0,000181 & 6,409459 \\
INP & 100 & 968,5632 & $1.961,257$ & $-4.680,834$ & $11.021,32$ \\
UWP & 100 & $4.878,298$ & $6.699,607$ & 25,66300 & $26.029,87$ \\
GWP & 100 & $5.056,807$ & $6.917,057$ & 29,11900 & $26.883,39$ \\
CLM & 100 & $3.664,780$ & $4.604,210$ & 18,72100 & $22.896,05$ \\
REI & 100 & $-172,6903$ & 249,2782 & $-859,5870$ & 133,8140 \\
LEV & 100 & $5.190,406$ & $14.021,41$ & 8,732000 & $62.917,49$ \\
SIZ & 100 & $14.550,53$ & $14.021,41$ & 313,5990 & $81.652,91$ \\
INR & 10 & 0,061000 & 0,012202 & 0,042500 & 0,077500 \\
GDP & 10 & 0,054160 & 0,005324 & 0,048800 & 0,062200 \\
\hline
\end{tabular}

Sumber: Data diolah, 2021

\section{Hasil regresi data panel}

Secara statistik, kemampuan prediksi model panel akan lebih baik jika nilai $\mathrm{p}$ (prob. $>x^{2}$ atau prob. $>$ F) lebih rendah dari 0,05. Berdasarkan hasil estimasi, ketiga model memiliki nilai p 0,000, mengindikasikan bahwa variabel independen secara bersamaan menjelaskan variabel dependen secara baik. Hasil perhitungan model empiris dijelaskan melalui Tabel 3.

\section{Premi bruto dan tingkat profitabilitas perusahaan asuransi}

Jumlah premi bruto memiliki pengaruh yang signifikan pada laba bersih keseluruhan dan pendapatan underwriting. Namun, pengaruh dari jumlah premi bruto terhadap kedua pengukuran profitabilitas perusahaan asuransi tersebut memiliki perbedaan. Hasil regresi menunjukkan adanya pengaruh negatif jumlah premi bruto terhadap laba bersih keseluruhan, sedangkan jumlah premi bruto menunjukkan adanya pengaruh positif terhadap tingkat pendapatan underwriting. Hal ini menunjukkan bahwa pertumbuhan premi meningkatkan profitabilitas melalui operasi inti perusahaan asuransi, namun pengelolaan risiko dan manajemen yang buruk dapat mempengaruhi pendapatan perusahaan asuransi jiwa secara keseluruhan. Temuan ini mendukung penemuan Akotey et.al (2013) mengenai perusahaan asuransi jiwa di Ghana serta penemuan Hrechaniuk et al. (2007) mengenai sektor asuransi di Spanyol, Lithuania, dan Ukraina.

Maka, jika perusahaan mengalokasikan lebih banyak sumber daya-khususnya pada sumber daya manusia dan sumber daya modal — untuk meningkatkan pertumbuhan premi tanpa alokasi yang proporsional pada manajemen aset dan liabilitas, maka pendapatan perusahaan akan menurun meskipun terdapat pertumbuhan premi bruto (GWP). Hasil empiris menunjukkan bahwa pertumbuhan yang cepat pada volume premi merupakan penyebab utama kebangkrutan perusahaan asuransi (Kim et al., 1995). Menurut Chen dan Wong (2004), terlalu terobsesi dengan pertumbuhan premium dapat menyebabkan self-destruction, mengingat tujuan penting lainnya (seperti pemilihan efektif dari portofolio yang menguntungkan untuk diinvestasikan) dapat ditelantarkan. Hal ini terbukti ketika terjadi adanya kemerosotan ekonomi, seperti di kawasan Asia dan Eropa, serta krisis keuangan global pada tahun 2007/2009.

\section{Pembayaran klaim dan tingkat profitabilitas perusahaan asuransi}

Tingkat pembayaran klaim memiliki pengaruh yang positif pada laba bersih keseluruhan (SAP) pada level signifikansi 1 persen. Implikasi dari hubungan positif antara klaim dan profitabilitas penjualan yaitu: jika produk asuransi yang dijual justru 
mengarah kepada risiko moral (moral hazard), seleksi yang merugikan, dan premi yang tinggi, maka klaim yang tinggi harus dibiayai melalui sumber pendapatan perusahaan asuransi.

\section{Total aset dan tingkat profitabilitas perusahaan asuransi}

Total aset memiliki pengaruh positif yang signifikan pada ketiga indikator profitabilitas di atas dengan tingkat signifikansi 5\%. Hal tersebut mengindikasikan bahwa adanya peningkatan nilai aset total, dengan menambah aset tetap seperti membuka cabang baru atau menerapkan teknologi baru menyebabkan perusahaan asuransi dapat meningkatkan underwriting polis yang secara langsung dapat meningkatkan keuntungan underwriting, laba bersih keseluruhan, serta pendapatan investasi. Pernyataan ini dapat dikonfirmasi karena adanya temuan yang serupa oleh Chen dan Wong (2004) dan Ahmed et al. (2011) pada industri asuransi Pakistan.

\section{Tingkat utang dan tingkat profitabilitas perusahaan asuransi}

Utang perusahaan pada 10 perusahaan asuransi jiwa yang dipilih terdiri dari utang klaim, utang koasuransi, utang reasuransi, utang komisi, utang pajak, biaya yang masih harus dibayar, dan utang lain. Penelitian ini menunjukkan bahwa terdapat efek negatif dari variabel utang pada laba bersih keseluruhan dan pendapatan investasi. Hasil sebaliknya didapatkan pada pendapatan underwriting, dimana peningkatan utang berdampak positif terhadap peningkatan pendapatan underwriting. Tingkat utang signifikan pada tingkat signifikansi 5\% pada pendapatan underwriting, sedangkan pada indikator lainnya tidak memiliki pengaruh yang signifikan. Penemuan ini berbeda dengan temuan Malik (2011) dan Charumathi (2012) yang menyatakan bahwa utang memiliki korelasi terbalik yang kuat terhadap profitabilitas.

\section{Tingkat bunga dan tingkat profitabilitas perusahaan asuransi}

Tingkat suku bunga acuan digunakan sebagai acuan oleh perusahaan asuransi dalam menentukan tingkat bunga yang dibayarkan kepada pemegang polis terhadap produknya

Tabel 3. Hasil regresi data panel

\begin{tabular}{llll}
\hline Variabel Independen & SAP & INP & UWP \\
\hline GWP & $-1,253625$ & $-266,2629$ & $1.650,999$ \\
CLM & $(0,0000)$ & $(0,6289)$ & $(0,0005)$ \\
& 0,340801 & 280,7571 & $-337,5003$ \\
REI & $(0,0924)$ & $(0,6076)$ & $(0,4807)$ \\
LEV & $-0,000923$ & & \\
& $(0,1106)$ & & \\
SIZ & $-0,0000108$ & $-0,008271$ & 0,089715 \\
& $(0,2473)$ & $(0,6998)$ & $(0,0001)$ \\
INR & 0,0000271 & 0,066860 & 0,162035 \\
& $(0,0239)$ & $(0,0009)$ & $(0,0000)$ \\
GDP & 3,391999 & $-20.926,95$ & $3.666,511$ \\
& $(0,4381)$ & $(0,1608)$ & $(0.7324)$ \\
YR2-YR10 & 25,34268 & $35.769,48$ & $-16.841,43$ \\
& $(0,0346)$ & $(0,3534)$ & $(0,5455)$ \\
CONST & 0,057837 & $-31,63009$ & 202,7938 \\
R^2 & $(0,6211)$ & $(0,9425)$ & $(0,5045)$ \\
Hausman Test & 5,744937 & $-575,1498$ & $-7.175,934$ \\
Sumber: Datadiolah & $(0,0001)$ & $(0,8152)$ & $(0.0028)$ \\
& 0,525079 & 0,396523 & 0,838543 \\
& $(1,0000)$ & $(1,0000)$ & $(1,0000)$ \\
\hline
\end{tabular}

Sumber: Data diolah, 2021 
Hasil penelitian Tabel 3 menunjukkan bahwa tingkat suku bunga memiliki dampak positif terhadap laba bersih keseluruhan dan pendapatan underwriting. Hal tersebut mengindikasikan bahwa pemegang polis cenderung meningkatkan penggunaan asuransi apabila ditawari suku bunga yang atraktif oleh perusahaan asuransi. Namun, efek sebaliknya dialami oleh pendapatan investasi, dimana semakin meningkatnya suku bunga, maka pendapatan investasi semakin turun. Tingkat suku bunga tidak memiliki pengaruh yang signifikan terhadap ketiga indikator profitabilitas.

\section{Indikator performa industri}

Performa finansial dari industri asuransi jiwa yang dianalisis oleh OJK yaitu mencakup rasio kecukupan premi terhadap pembayaran klaim, rasio kecukupan premi terhadap pembayaran klaim dan biaya umum, rasio kecukupan premi dan hasil investasi terhadap pembayaran klaim, rasio kecukupan premi dan hasil investasi terhadap pembayaran klaim dan biaya umum, rasio sesi asuransi, serta rasio investasi terhadap cadangan teknis. Rasio dari industri asuransi jiwa pada setiap bulan Desember pada periode tahun 2016-2019 ditunjukkan pada Tabel 4.

\section{Rasio kecukupan premi dan hasil investasi}

Perhitungan ini mencakup rasio kecukupan premi terhadap pembayaran klaim, rasio kecukupan premi terhadap pembayaran klaim dan biaya umum, rasio kecukupan premi dan hasil investasi terhadap pembayaran klaim, rasio kecukupan premi dan hasil investasi terhadap pembayaran klaim dan biaya umum. Berdasarkan perhitungan, industri asuransi jiwa di Indonesia menunjukkan penurunan performa yang signifikan pada tahun 2016 hingga tahun 2019, ditunjukkan dengan penurunan rasio dari tahun ke tahun. Hal tersebut menunjukkan semakin tinggi klaim yang diajukan oleh tertanggung kepada perusahaan asuransi jiwa dibandingkan dengan premi yang diberikan oleh tertanggung.

Tabel 4. Rasio industri asuransi jiwa

\begin{tabular}{|c|c|c|c|c|}
\hline Rasio & 2016 & 2017 & 2018 & 2019 \\
\hline $\begin{array}{l}\text { Kecukupan Premi terhadap Pembayaran Klaim } \\
(\%)\end{array}$ & 223,67 & 158,8 & 130,7 & 120,9 \\
\hline $\begin{array}{l}\text { Kecukupan Premi terhadap Pembayaran Klaim } \\
\text { dan Biaya Umum }(\%)\end{array}$ & 162,96 & 138,5 & 116,5 & 107,9 \\
\hline $\begin{array}{l}\text { Kecukupan Premi dan Hasil Investasi terhadap } \\
\text { Pembayaran Klaim }(\%)\end{array}$ & 238,42 & 200,1 & 135,3 & 135,2 \\
\hline $\begin{array}{l}\text { Kecukupan Premi dan Hasil Investasi terhadap } \\
\text { Pembayaran Klaim dan Biaya Umum }(\%)\end{array}$ & 173,71 & 174,5 & 120,6 & 120,6 \\
\hline Sesi Asuransi (\%) & 45,96 & 2,6 & 2,8 & 3,2 \\
\hline Investasi terhadap Cadangan Teknis (\%) & 114,36 & 115,4 & 113,3 & 112,4 \\
\hline
\end{tabular}

Sumber: Otoritas Jasa Keuangan, 2021(diolah)

Berdasarkan kondisi tersebut, dapat disimpulkan bahwa risiko perusahaan asuransi jiwa atas risiko likuiditas dan solvabilitas meningkat setiap tahunnya. Jika rasio kecukupan terus mengalami penurunan, hal tersebut akan meningkatkan risiko perusahaan asuransi jiwa dalam jangka pendek maupun panjang, serta menghambat pertumbuhan dan perkembangan perusahaan. 


\section{Sesi asuransi}

Seperti yang terlihat pada Tabel 4, rasio sesi asuransi mengalami penurunan yang sangat signifikan pada tahun 2017, yaitu sebesar 43,36\% menjadi 2,6\%, yang menandakan bahwa sebagian obligasi pada portofolio polis perusahaan yang ditransfer ke perusahaan reasuransi mengalami penurunan. Hal tersebut terjadi akibat dari biaya dari proses sesi asuransi yang lebih tinggi dibandingkan hasil yang didapatkan.

\section{Investasi terhadap cadangan teknis}

Investasi terhadap cadangan teknis juga mengalami penurunan pada tahun tiga tahun terakhir. Hal tersebut disebabkan karena adanya penurunan investasi pada portofolio perusahaan asuransi yang mengandung risiko yang semakin tinggi. Investasi pada produk yang memiliki risiko tinggi menyebabkan biaya yang ditimbulkan meningkat, maka dari itu, adanya penurunan rasio tersebut merupakan upaya bagi perusahaan asuransi untuk mengurangi biaya.

\section{KESIMPULAN DAN SARAN}

\section{Kesimpulan}

Penelitian ini mengukur tingkat profitabilitas dari perusahaan-perusahaan asuransi jiwa di Indonesia, dengan analisis mendalam pada faktor-faktor penentu profitabilitas. Performa finansial perusahaan asuransi jiwa diukur melalui tiga parameter, yaitu laba bersih keseluruhan, pendapatan investasi, serta pendapatan underwriting. Ketiga parameter diatas menguji tiga operasi utama dari perusahaan asuransi. Pada umumnya, laba bersih keseluruhan dari perusahaan asuransi merupakan penjumlahan dari pendapatan investasi dan pendapatan underwriting. Indikator pendapatan investasi dan pendapatan underwriting saling melengkapi satu sama lain untuk meningkatkan tingkat profitabilitas keseluruhan dari perusahaan asuransi.

Berdasarkan OJK, performa perusahaan asuransi jiwa di Indonesia mengalami penurunan, dilihat melalui kecukupan premi dan hasil investasi terhadap pembayaran klaim. Studi lebih lanjut menunjukkan bahwa tingkat pembayaran klaim memiliki pengaruh yang positif pada laba bersih keseluruhan, sedangkan tingkat utang memiliki pengaruh positif terhadap pendapatan underwriting. Selanjutnya, temuan menunjukkan bahwa peningkatan premi bruto memiliki pengaruh yang signifikan secara positif pada pendapatan underwriting, namun memiliki pengaruh negatif pada laba secara keseluruhan. Terdapat faktor pengelolaan risiko dan manajemen yang dapat mempengaruhi pendapatan perusahaan, terutama pada bagian investasi perusahaan. Nilai dari instrumen investasi sedang berada pada tingkat volatilitas yang tinggi akibat beberapa peristiwa yang terjadi di Indonesia.

\section{Saran}

Pengelolaan risiko investasi yang tepat dari perusahaan asuransi jiwa merupakan langkah antisipatif untuk terhindar dari efek negatif volatilitas nilai investasi. Pengelolaan tingkat premi juga disesuaikan dengan kondisi yang terjadi pada pasar asuransi serta kondisi makroekonomi di Indonesia dikarenakan peningkatan nilai premi tidak selalu mengindikasikan bahwa adanya peningkatan laba secara keseluruhan. Faktor makroekonomi seperti hubungan dengan negara lain, nilai tukar mata uang, serta 
kebijakan perdagangan internasional juga merupakan aspek yang diperhitungkan dalam pengelolaan risiko asuransi jiwa.

\section{DAFTAR PUSTAKA}

Adiel, R. (1996). Reinsurance and the management of regulatory ratios and taxes in the property-casualty insurance industry. Journal of Accounting and Economics, 22(1-3), 207-240. doi:10.1016/s0165-4101(96)00436-3.

Ahmed, N., Ahmed, Z., \& Ahmed, I. (2010). Determinants of capital structure: a case of life insurance sector of Pakistan. Euro Journals, 24.

Ahmed, N., Ahmed, Z., \& Usman, A. (2011). Determinants of performance: A case of life insurance sector of Pakistan. International Research Journal of Finance and Economics, 61, 123-128.

Akotey, J. O., Sackey, F. G., Amoah, L., \& Manso, R. F. (2013). The financial performance of life insurance companies in Ghana. The Journal of Risk Finance, 14(3), 286-302. https://doi.org/10.1108/jrf-11-2012-0081.

Badan Pusat Statistik. (2020). [Seri 2010] Sumber pertumbuhan PDB Seri 2010 (Persen), 2010-2020. Badan Pusat Statistik: Jakarta.

Barniv, R., \& Hershbarger, R. A. (1990). Classifying financial distress in the life insurance industry. The Journal of Risk and Insurance, 57(1), 110. doi: $10.2307 / 252927$.

Bawa, S.K. \& Chattha, S. (2013). Financial performance of life insurers in Indian insurance industry. Pacific Business Review International, 6(5), 44-52.

Burca, A.M. \& Batrinca, G. (2014). The determinants of financial performance in the romanian insurance market. International Journal of Academic Research in Accounting, Finance and Management Sciences, 4(1), 299-308.

Buyinza, F., Francois, J. \& Landesmann, M. (2010). Determinants of Profitability of Commercial Banks in Sub Saharan Africa Countries. Department of Economics, Johannes Kepler University, Linz.

Chang, C.P. (2006). Establishing a performance prediction model for insurance companies. The Journal of American Academy of Business, Cambridge, 8(1), 7377.

Charumathi, B. (2012). On the determinants of profitability of Indian life insurers - an empirical study. Proceedings of the World Congress on Engineering, 1(2), 4-6.

Chen, R., \& Wong, K. (2004). The determinants of financial health of Asian insurance companies. Journal of Risk and Insurance, 71, 469-499.

Chen, Y., Hamwi, I. S., \& Hudson, T. (2001). The effect of ceded reinsurance on solvency of primary insurers. International Advances in Economic Research, 7(1), 65-82. doi:10.1007/bf02296592.

Greene, W. H., \& Segal, D. (2004). Profitability and efficiency in the US life insurance industry. Journal of Productivity Analysis, 21(3), 229-247.

Gron, A., \& Deborah J. Lucas, 1998. "External financing and insurance cycles, NBER Chapters, in: The Economics of Property-Casualty Insurance, IDEAS. 5-28, National Bureau of Economic Research, Inc.

Hemrit, W. \& Benlagha, N. (2019). Asymmetric impacts of insurance premiums on the non-oil GDP: some new empirical evidence. Applied Economics, 59(61), 1-15.

Hemrit, W. (2019). Determinants driving Takaful and cooperative insurance financial performance in Saudi Arabia. Journal of Accounting \& Organizational Change, 16(1), 123-143. doi:10.1108/jaoc-03-2019-0039. 
Hrechaniuk, B., Lutz, S. \& Talavera, O. (2007). Do the determinants of insurers' performance in "old" EU and the "New" EU and outside?. Dalam www.webmeets.com/files/pape/EARIE/2007/155/Ins-GLT-EARIE.pdf. Diakses 12 Desember 2020, Pukul 12.30 WIB

Kim, Y.D., Anderson, D.R., Amburgey, T.L. and Hickman, J.C. (1995). The use of event history analysis to examine insurers insolvencies, Journal of Risk and Insurance, $62,94-110$

Kumari, T.H. (2013). Performance evaluation of Indian life insurance industry in post liberalization. International Journal of Social Sciences Arts and Humanities, 1(1), 7-14.

Kusi, B. A., Alhassan, A. L., Ofori-Sasu, D., \& Sai, R. (2019). Insurance regulations, risk and performance in Ghana. Journal of Financial Regulation and Compliance, 28(1), 74-96. doi:10.1108/jfrc-09-2018-0126.

Lee, C., \& Lin, C. (2016). Globalization, political institutions, financial liberalization, and performance of the insurance industry. The North American Journal of Economics and Finance, 36, 244-266. doi:10.1016/j.najef.2016.01.007.

Liargovas, P. G., \& Skandalis, K. S. (2010). Factors affecting firms' performance: The case of Greece. Global Business and Management Research: International Journal, 2(2-3), 184

Malik, H. (2011). Determinants of insurance companies profitability: an analysis of insurance sector of Pakistan. Academic Research International, 1(3), 315-321.

Mohy Ul Din, S., Abu-Bakar, A., \& Regupathi, A. (2017). Does insurance promote economic growth: a comparative study of developed and emerging/developing economies. Cogent Economics and Finance, 5, 1-12.

N.N. (2020). BI 7-day (Reverse) Repo Rate. Dalam https://www.bi.go.id/en/moneter/bi7day-RR/data/Contents/Default.aspx. Diakses 12 Desember 2020.

N.N. (2020). Data BI rate dan BI 7-day (reverse) repo rate. Dalam https://www.sahamok.net/bi-rate/. Diakses 13 Desember 2020.

Omondi, M. M., \& Muturi, W. (2013). Factors affecting the financial performance of listed companies at the Nairobi Securities Exchange in Kenya. Research Journal of Finance and Accounting, 4(15), 99-104.

Otoritas Jasa Keuangan (2020). Statistik asuransi. Otoritas Jasa Keuangan: Jakarta.

Otoritas Jasa Keuangan. (2020). Direktori asuransi. Otoritas Jasa Keuangan: Jakarta.

Sharma, A., Jadi, D. M., \& Ward, D. (2018). Evaluating financial performance of insurance companies using rating transition matrices. The Journal of Economic Asymmetries, 18. doi:10.1016/j.jeca.2018.e00102.

Shiu, Y. (2020). How does reinsurance and derivatives usage affect financial performance? Evidence from the UK non-life insurance industry. Economic Modelling, 88, 376-385. doi:10.1016/j.econmod.2019.09.048.

Suvvari, A., S., R. S., \& Goyari, P. (2019). Financial performance assessment using Grey relational analysis (GRA). Grey Systems: Theory and Application, 9(4), 502-516. doi:10.1108/gs-05-2019-0010.

$\mathrm{Yu}$, C. (2015). Financial policies on firm performance: The U.S. insurance industry before and after the global financial crisis. Economic Modelling, 51, 391-402. doi:10.1016/j.econmod.2015.08.029.

Zainudin, R., Mahdzan, A.N. \& Leong, E. (2018). Firm-specific internal determinants of profitability performance: an exploratory study of selected life insurance firms in Asia. Journal of Asia Business Studies, 12(4), 533-550. 